Original Paper

\title{
Pelatihan Pemantapan Konsep Materi Fisika dan Pengukuran Bagi Guru IPA di SMPN 9 Mataram
}

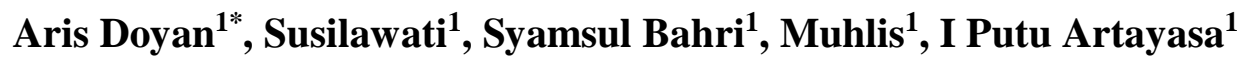 \\ ${ }^{1}$ Program Studi Magister Pendidikan IPA, Pascasarjana, Universitas Mataram, Indonesia
}

DOI: $10.29303 /$ jpmpi.v2i1.333

Sitasi: Doyan, et, al. (2019). Pelatihan Pemantapan Konsep Materi Fisika dan Pengukuran Bagi Guru IPA di SMPN 9 Mataram. Jurnal Pengabdian Magister Pendidikan IPA (JPMPI). (2) 1. pp. 24-27

*Corresponding Author: Aris Doyan, Program Studi Magister Pendidikan IPA, Pascasarjana, Universitas Mataram,

Indonesia;

Email:

aris_doyan@unram.ac.id

\begin{abstract}
Abstrak: Mata pelajaran IPA merupakan mata pelajaran pada jenjang Sekolah Menengah Pertama (SMP) yang materinya merupakan keterpaduan antara biologi, kimia dan fisika. Namun, masih banyak guru yang belum memiliki latar belakang pendidik IPA. Guru IPA di SMP kota Mataram kebanyakan berlatar belakang biologi, maupun fisika. Bagi guru yang memiliki latar belakang pendidikan biologi, mereka merasa kesulitan dalam membimbing siswanya untuk mengkaji materi fisika. Dengan terpaksa guru IPA yang tidak mempunyai latar belakang IPA secara utuh harus tetap mengajarkan IPA kepada siswanya, akibatnya siswa tidak dapat memahami materi IPA secara utuh. Berdasarkan analisis kompetensi dasar pada masing-masing jenjang kelas di SMP, terdapat 33\% kompetensi dasar yang merupakan kajian fisika, dan sisanya $67 \%$ merupakan kajian biologi dan kimia. Berdasarkan observasi yang telah dilakukan, guru IPA yang tidak memiliki latar belakang IPA secara utuh merasa kurang percaya diri dalam menyampaikan materi IPA. Pelatihan yang dilaksanakan mendapatkan respon positif dari guru peserta dan pelaksanaan PKM berhasil diketahui dari tingkat kehadiran peserta mencapai $90 \%$..
\end{abstract}

Keywords: Materi fisika dan Pengukuran.

\section{Pendahuluan}

Pembelajaran fisika di SMP merupakan sebuah bagian dari mata pelajaran IPA yang materinya memiliki presentase yang cukup besar. Pada jenjang kelas VII terdapat sebelas kompetensi dasar, terdapat tiga kompetensi dasar yang cakupan materinya merupakan bagian dari fisika dan delapan merupakan bagian dari biologi (Sari dan Surahmi, 2019). Pada jenjang kelas VIII terdapat dua belas kompetensi dasar, dimana terdapat lima kompetensi dasar yang cakupannya adalah fisika. Sedangkan pada jenjang kelas IX terdapat sepuluh kompetensi dasar, empat diantaranya adalah khusus pada materi fisika (BSNP, 2019).

Guru IPA SMP di kota Mataram banyak yang berlatar belakang guru pendidik mata pelajaran biologi maupun mata pelajaran fisika. Sehingga guru yang berlatar belakang biologi merasa kesulitan ketika mempelajari IPA pada ranah fisika. Peranan guru dalam pelaksanaan pembelajaran sangat berpengaruh terhadap kemampuan siswa untuk memahami materi yang mereka pelajari (Sukaesih, et al., 2017). Hal itu juga harus didukung oleh kemampuan guru dalam memahami materi-materi secara utuh dan sesuai dengan hirarki konsep IPA khususnya materi fisika (Sukaesih, et al., 2017), (Prasetyaningsih dan Wilujeng, 2016).

Guru IPA yang berlatar belakang pendidikan nonfisika kurang mampu memahami materi IPA khususnya pada materi fisika. Oleh karena itu, guru-guru IPA SMPN sangat perlu diberikan bimbingan dalam menguasai materi fisika khususnya bagi guru yang berlatar belakang nonfisika. 


\section{Metode Pelaksanaan}

Menanggapi permasalahan yang menjadi kesulitan guru-guru IPA SMP di kota Mataram yang merasa kesulitan dalam membelajarkan IPA, maka permasalahan ini dapat diselesaikan dengan cara memberikan pelatihan kepada para guru IPA yang tidak berlakang IPA secara utuh. Beberapa tahapan yang akan dilalui dalam penyelesaian masalah ini yaitu tahap persiapan (plan), tahap pelaksanaan, dan tahap evaluasi (Doyan, et al., 2018).

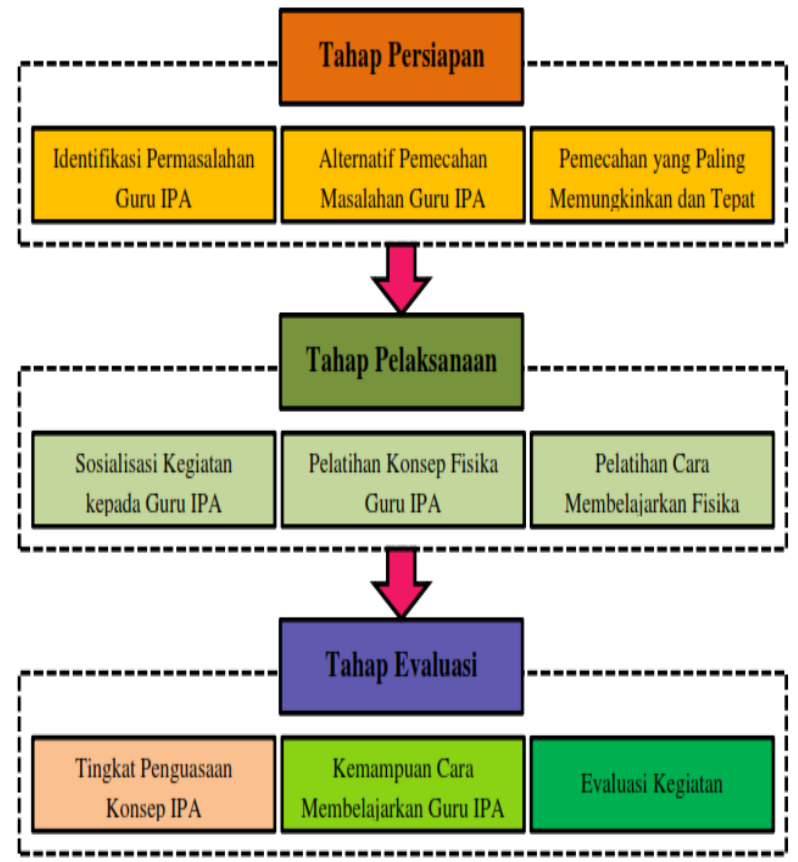

Gambar 1. Kerangka Metode Pelaksanaan Pelatihan Guru IPA SMP

\section{Tahap Persiapan}

Pada tahap persiapan dilakukan wawancara langsung terhadap guru mata pelajaran IPA SMP, guna untuk mengidentifikasi permasalahan yang dihadapi dalam proses pembelajaran. Hasil identifikasi ditemukan bahwa guru IPA yang berlatar belakang biologi mengalami kendala dalam pelaksanaan pembelajaran IPA pada kompetensi dasar atau materi fisika, sedangkan guru IPA yang berlatar belakang fisika mengalami kesulitan dalam membelajarkan materi biologi. Salah satu upaya untuk menyelesaikan masalah tersebut adalah dengan dilakukan pelatihan kepada guru IPA khusus pada materi fisika dan biologi agar guru dapat menguasai konsep dan cara mengajarkannya kepada siswa.

\section{Tahap Pelaksanaan}

Pada tahap pelaksanaan ini merupakan tindak lanjut untuk menyelesaikan permasalahan IPA yang dialami guru SMP yaitu dengan dilaksanakan pelatihan langsung mengenai analisis kompetensi dasar, analisis materi esensial, dan dilanjutkan ke analisis konsep yang terkandung di dalam kompetensi dasar dan pelatihan konsep fisika dan biologi guru dan cara mengajarkannya.

\section{Tahap Evaluasi dan Pelaporan}

Evaluasi hasil pelatihan dilakukan secara langsung dengan mengobservasi kegiatan pembelajaran yang dilaksanakan guru IPA.

Ada 2 aspek yang dievaluasi pada kegiatan ini, yaitu: (a) Aktivitas peserta selama pelatihan berlangsung. Keberhasilan dapat dilihat dari kehadiran dan aktivitas peserta selama kegiatan baik bertanya, menjawab pertanyaan dan berdiskusi. Kegiatan dikatakan berhasil jika minimal $85 \%$ sasaran hadir, dan minimal $85 \%$ peserta yang hadir mengikuti kegiatan secara penuh. (b) Tingkat kemampuan membelajarkan meningkat jika guru merasa percaya diri dalam menyampaikan pembelajaran IPA dan membelajarkannya dengan tepat sesuai karakteristik materi ajar.

\section{Hasil dan Pembahasan}

Kegiatan PKM diawali dengan koordinasi dengan kepala sekolah SMP N 9 Mataram untuk membahas permohonan kerjasama dalam pelaksanaan kegiatan pengabdian. Hal ini dilakukan agar kegiatan yang dilakukan tepat pada sasaran dan diikuti sepenuhnya oleh para guru IPA SMP N 9 Mataram. Dalam pertemuan tersebut tim PKM memberikan ulasan tentang kegiatan yang akan dilaksanakan, yaitu berkaitan dengan pelatihan kepada guru IPA terutama yang berlatar belakang nonfisika. Umumnya guru mata pelajaran IPA tidak semua berlatar belakang fisika, sehingga sering mengalami kesulitan dalam melaksanakan pembelajaran pada materi fisika.

Kegiatan pertama yang dilakukan adalah sosialisasi kegiatan kepada guru-guru IPA yang mengikuti kegiatan pelatihan pamantapan konsep materi fisika dan pengukuran. Kegiatan sosialisasi diikuti oleh kepala sekolah dan guru-guru IPA SMP N 9 Mataram. 


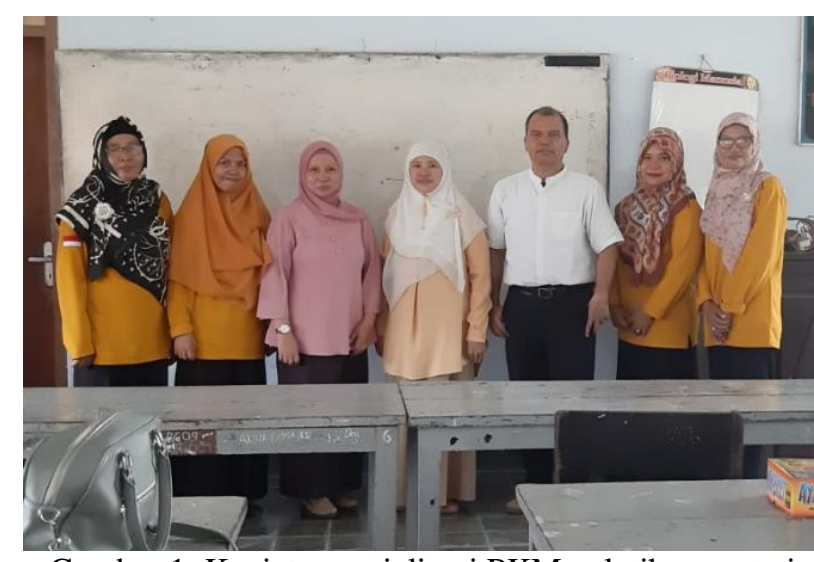

Gambar 1. Kegiatan sosialisasi PKM pelatihan materi fisika dan pengukuran.

Langkah awal dalam menyelesaikan permasalahan yang dialami oleh guru IPA SMP adalah dengan terlebih dahulu menganalisis kompetensi dasar yang ada di dalam kurikulum 2013 revisi 2017 (Suardana, et al., 2013). Analis kompetensi dasar ini sangat perlu dilakukan untuk mengetahui batasan-batasan materi yang harus disampaikan dan materi yang esensial untuk dipahami oleh guru yang bersangkutan khususnya pada materi cakupan fisika dan biologi. Kompetensi dasar yang cakupannya adalah fisika dan biologi kemudian dijadikan acuan dalam pelaksanaan pelatihan guru terkait dengan konsep-konsep dan cara membelajarkannya kepada siswa.

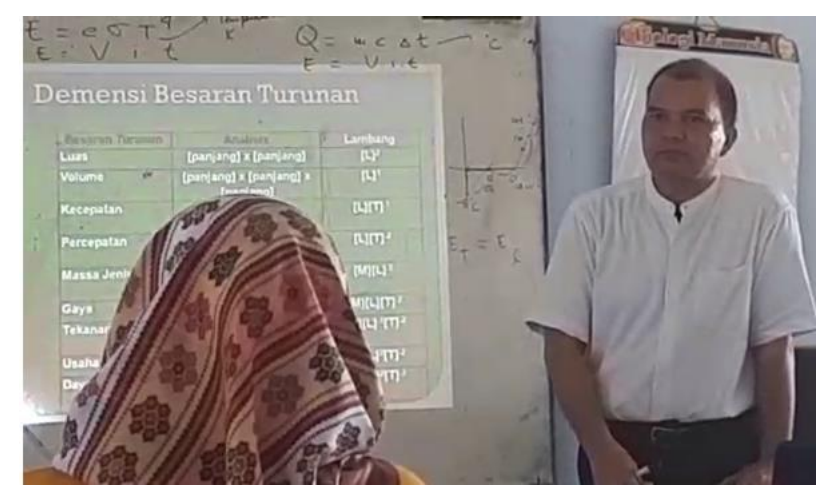

Gambar 2. Kegiatan bimbingan pemantapan konsep fisika guru.

\footnotetext{
Pembelajaran IPA hendaknya dilakukan melalui penyajian permasalahan kontekstual dengan harapan akan dapat membantu pemahaman siswa dan menggeser persepsi siswa yang menganggap bahwa pembelajaran IPA itu sulit (Oktaviani, et al., 2017). Dengan penyajian fenomena yang kontekstual di lingkungan seharihari siswa (Gitriani, et al., 2018), akan
}

menumbuhkan rasa kebermanfaatan terhadap materi IPA yang ada di sekitar kehidupan yang dapat diselidiki secara ilmiah.

Hasil evaluasi kegiatan pelatihan fisika bagi guru SMP N 9 Mataram terlaksana dengan baik. Hal ini ditandai dengan tingkat kehadiran guru sebagai peserta pembinaan $90 \%$ dengan kehadiran tepat waktu dan memberikan respon positif

\section{Kesimpulan}

Kegiatan Pengabdian Kepada Masyarakat ini dilaksanakan di SMP N 9 Mataram. Pelaksanaan kegiatan dapat meningkatkan pemahaman konsep fisika bagi guru yang berlatar belakang nonfisika. Kegiatan ini mendapat respon positif dari guru peserta pelatihan dan tingkat kehadiran guru mencapai $90 \%$.

\section{Saran}

Beberapa hal yang diharapkan oleh guru IPA yang latar belakangnya nonfisika adalah kegiatan pelatihan konsep fisika sekaligus merancang sebuah alat sederhana untuk mendemonstrasikan konsep tersebut kepada siswa.

\section{Ucapan Terima Kasih}

Terima kasih kami ucapkan kepada Rektor Universitas Mataram dan Ketua Lembaga Penelitian dan Pengabdian Kepada Masyarakat Universitas Mataram yang telah mendanai PKM ini. Ucapan terima kasih juga kami sampaikan kepada semua pihak.

\section{Daftar Pustaka}

Sari, K., \& Surahmi, N. (2019). Persepsi Guru Fisika SMP Kota Banda Aceh terhadap Pelaksanaan Pembelajaran Tematis. Jurnal Pendidikan, sains, dan humaniora Serambi Akedemia (7), 3.

Badan Standar Nasional Pendidikan (2019). Peraturan Menteri Pendidikan dan Kebudayaan Republik Indonesia Nomor 37 Tahun 2018. BSNP. 
Sukaesih, S., Ridlo, S., Saptono, S. (2017). Profil

Kemampuan Pedagogical Content Knowledge (PCK) Calon Guru Biologi. Journal of Education Research.

Prasetyaningsih, \& Wilujeng, I. (2016). Analisis

Kualitas Pengelolaan Kelas Pembelajaran Sains Pada SMP SSN di Kabupaten Pati. Jurnal Penelitian dan Pembelajaran IPA (2), 2.

Doyan, A., Susilawati, Soeprianto, H., Bahri, S. (2018). Pelatihan Olimpiade MIPA Bagi Guru dan Peserta Didik SMA Kesuma Mataram. Jurnal Pengabdian Magister Pendidikan IPA 2018, (1) $1: 20$ - 23.

Suardana, I. K., Sudiatmika, A. R., Oktofa, D. (2013). Pendampingan Penyusunan Asesmen Fisika Berbasis OSN Bagi Guru SMP di Kota Tabanan. Jurnal Pengabdian Kepada Masyarakat Widya Laksana (2) 1.

Oktaviani, W., Gunawan, Sutrio. (2017). Pengembangan Bahan Ajar Fisika Kontekstual Untuk Meningkatkan Penguasaan Konsep Siswa. Jurnal Pendidikan Fisika dan Teknologi (3), 1.

Gitriani, R., Aisah, S., Hendriana, H., Herdiman, I. (2018). Pengembangan Lembar Kerja Siswa Berbasis Pendekatan Kontekstual pada Materi Lingkaran untuk Siswa SMP. Jurnal Review Pembelajaran Matematika (3), 1. 